\title{
Frekuensi konsumsi growol berhubungan dengan angka kejadian diare di Puskesmas Galur II Kecamatan Galur Kabupaten Kulonprogo Provinsi DIY
}

\author{
Anastasia Eni R , Lily Arsanti Lestari², M.Juffrie ${ }^{3}$
}

\begin{abstract}
Background: Diarrhea is a serious health problem in developing countries because $25 \%$ of total mortality rate among children in the world is caused by diarrhea and has caused 3-4 million of children to die annually. In Indonesia diarrhea is also a major health problem whereby morbidity rate of diarrhea in 2004 was still relatively high, i.e. 280/1000 population and the second cause of death in underfives. At the working area of Galur II Health Center mortality rate caused by diarrhea in 2007 increased from none to 2 deaths in underfives (3.14/1000) and diarrhea was in the first rank of 10 major diseases in inpatient service activities. One cause of diarrhea is imbalance of intestinal microbes in the digestive tract. This is due to two groups of bacteria (harmful and useful/probiotic bacteria) that kill each other. Previous studies on the potential of probiotic show that Lactobacillus rhamnosus GG was effective in preventing diarrhea and shortening the duration of diarrhea. Growol contains Lactobacillus case subsp. Rhamnosus TGR 2 that has the potential as probiotic.

Objective: To identify association between frequency of growol consumption and the prevalence of diarrhea.

Method: The study was observational with cross sectional design carried out at the area of Galur II Health Center, Subdistrict of Galur, District of Kulonprogo, Province of Yogyakarta Special Territory. Population of the study were children of 1-5 years old with criteria willing to be studied, were not malnourished and came for weighing at Posyandu (integrated service post) in November 2008. Data collected were analyzed using linear regression test at significance 95\% and descriptively.

Result: Out of 472 underfives, 244 (52\%) were boys and 228 (48\%) girls; 22.4\% had diarrhea and 77.54\% had never had diarrhea; 160 consumed growol and 12 of them (7.5\%) had diarrhea; 312 did not consume growol and 94 of them (30.52\%) had diarrhea. Respondents consumed growol in average 3.8 times/week. There was association between frequency of growol consumption and the prevalence of diarrhea according to the equivalent $Y=0.474-0.079 \times \mathrm{or}$ growol could prevent diarrhea if consumed minimum 6.4 times/week.

Conclusion: There was association between frequency significant relationship between growol frequency consumption and diarrhea rate.
\end{abstract}

KEY WORDS growol, growol frequency consumption, diarrhea rate

\section{PENDAHULUAN}

Diare masih menjadi masalah serius, terutama di negara-negara berkembang. Menurut perkiraan Organisasi Kesehatan Dunia (WHO), di tahun 2000 terjadi sekitar 150 juta kasus diare pada anak-anak di seluruh dunia. Hal itu telah menyebabkan $3-4$ juta anak meninggal. Di negara berkembang 25 persen dari jumlah total kematian anak disebabkan oleh diare (1).

Di Indonesia diare masih menjadi masalah kesehatan dan penyakit ini dapat terjadi pada semua golongan usia. Angka kesakitan penyakit diare di Indonesia pada tahun 2004 masih cukup tinggi yaitu 280/1000 penduduk dan menempati urutan ke 3 penyebab kematian bayi,urutan ke 2 pada balita dan nomor 5 pada semua umur dan sering timbul dalam bentuk kejadian luar biasa (KLB) dengan kematian cukup tinggi menurut Survei Kesehatan Rumah Tangga (SKRT) 2004 (2).

Salah satu penyebab terjadinya diare karena adanya ketidakseimbangan flora usus dalam saluran pencernaan (usus). Hal ini disebabkan karena di dalam usus bukan hanya berisi sari dan sisa makanan, namun juga berbagai jenis bakteri. Bakteri-bakteri tersebut berasal dari ratusan spesies yang berbeda dan terdapat dalam jumlah yang sangat besar (diperkirakan seratus triliun bakteri). Bakteribakteri yang menghuni usus manusia dinamakan bakteri saluran usus.Di dalam usus khususnya usus kecil dan usus besar terdapat sekitar 104-1011 cfu/g yang berasal dari 400 hingga 500 jenis atau sama dengan $1,5 \mathrm{~kg}$ mikroorganisme yang berbeda (3).

Bakteri yang sangat banyak tersebut digolongkan menjadi dua jenis, yakni bakteri baik dan bakteri jahat. Bakteri baik yaitu bakteri yang keberadaannya menguntungkan bagi manusia (probiotik) di antaranya Lactobacillus dan Bifidobacteria. Sementara bakteri jahat yaitu bakteri yang keberadaannya merugikan

\footnotetext{
Puskesmas Dlingo 1, Dinas Kesehatan Bantul, Daerah Istimewa Yogyakarta, e-mail: eni.anastasia@gmail.com

2 Program Studi Gizi Kesehatan Fakultas Kedokteran UGM Yogyakarta, e-mail: santi_wap@yahoo.com

${ }^{3}$ Bagian Anak RSUP Dr. Sardjito, JI. Kesehatan, Yogyakarta, e-mail: juffrie@indosat.net.id
} 
atau menyebabkan sakit (bakteri patogen) antara lain Escherichia coli, Closteridium perfringence, Salmonella, dan Staphylococcus. Di dalam usus, kedua jenis bakteri ini saling bergolak dan membunuh.

Proses pergolakan yang terjadi tersebut ternyata mengandung konsekuensi serius terhadap kesehatan tubuh manusia, serta erat kaitannya dengan peluang terjadinya penyakit seperti diare karena pertumbuhan bakteri jahat lebih banyak (2).

Berdasarkan fenomena tersebut, perlu dilakukan manajemen flora usus yaitu proporsi bakteri jahat ditekan jumlahnya, dan bakteri baik ditingkatkan. Salah satu caranya dengan mengkonsumsi bakteri probiotik. Probiotik adalah pangan atau suplemen pangan yang berisi mikroba hidup yang dapat memberikan efek menguntungkan bagi usus. Mikrobia hidup tersebut dapat memberikan efek yang menguntungkan bagi kesehatan jika dikonsumsi dalam jumlah yang cukup (4). Banyak penelitian untuk mengetahui manfaat probiotik bagi kesehatan, di antaranya yaitu penelitian potensi probiotik sebagai alternatif baru mencegah dan mengobati diare (5) dan penelitian lain menyebutkan bahwa probiotik Lactobacillus rhamnosus GG efektif mencegah diare, mengatasi diare akut serta memperpendek durasi diare (6).

Indonesia merupakan negara yang kaya akan sumber bahan pangan dan setiap daerah memiliki makanan tradisional yang khas dan tidak dijumpai di daerah lain. Beberapa makanan tradisional Indonesia yang berupa makanan fermentasi ditengarai memiliki manfaat kesehatan, seperti dadih dari Sumatera Barat, gatot dan growol asli dari Yogyakarta.

Growol merupakan salah satu pangan fungsional asli Yogyakarta khususnya daerah Kulon Progo dan sekitarnya yang digunakan sebagai pengganti nasi, mengandung bakteri asam laktat yang mampu berperan sebagai probiotik. Penelitian, mengenai potensi bakteri probiotik yang diisolasi dari sumber lokal (probiotik indigenous) di Indonesia menunjukkan bahwa bakteri asam laktat dari gatot (Lactobacillus plantarum Mut7 dan Lactobacillus sake Mut13), growol (Lactobacillus casei subsp. rhamnosus TGR2), tape singkong (Lactobacillus plantarum), tempoyak (Lactobacillus fermentum), asinan rebung (Lactobacillus acidophilus), tempe (Lactobacillus casei subsp.rhamnosus TTE1) mampu bertahan pada suasana asam di saluran cerna, tahan dalam konsentrasi garam empedu, tetapi yang memiliki potensi aktivitas antimikrobia hanya Lactobacillus casei subsp. rhamnosus TGR2 yang diisolasi dari growol (7).

Beberapa bakteri asam laktat yang diisolasi dari gatot dan dadih yaitu Lactobacillus plantarum Mut7, Lactobacillus sake Mut13, Lactobacillus sp Dad 13 dan Lactobacillus sp. Dad11 mampu menghambat beberapa bakteri pathogen seperti Salmonella typhi, Staphylococcus aureus dan E. Coli (8). Mikrobia yang dominan pada gatot adalah bakteri yang bersifat amilolitik karena kandungan amilosanya cukup tinggi namun jumlah bakteri asam laktat yang terdapat di dalam gatot tidak terlalu besar (9).

Jumlah bakteri amilolitik dan bakteri yang mampu membentuk asam (fermentatif) yang tumbuh dengan sendirinya tanpa diinokulasi dengan isolate bakteri lain pada growol tiap gramnya sebesar 1,64 x 108 (10). Beberapa keuntungan Lactobacillus casei subsp. rhamnosus TGR2 yang diisolasi dari growol adalah sifat metabolit ekstraseluler yang tetap stabil pada suhu kamar, pada pemanasan $98^{\circ} \mathrm{C}$ tahan selama 30 menit, $\mathrm{pH} 3-8$; pada pemanasan $121^{\circ} \mathrm{C}$ selama 15 menit; dan pada suhu $4^{\circ} \mathrm{C}$ selama 21 hari (11).

Di wilayah kerja Puskesmas Galur II tahun 2008 angka kematian balita mengalami peningkatan dari tidak ada menjadi 2 kematian yaitu sebesar 3,14/1000 balita. Dari 2 kematian balita tersebut salah satunya meninggal dengan diagnosis infeksi saluran pencernaan. Berdasarkan pola penyakit yang ada di masyarakat dilihat dari sepuluh besar penyakit pada kegiatan pelayanan rawat inap selama tahun 2007, urutan pertama adalah Gastroenteritis Akut (diare) yaitu sebanyak 61 kasus $(15,4 \%)$.

Penelitian ini bertujuan untuk mengetahui hubungan frekuensi konsumsi growol dengan angka kejadian diare di wilayah kerja Puskesmas Galur II, Kecamatan Galur, Kabupaten Kulon Progo, Provinsi DIY.

\section{BAHAN DAN METODE}

Penelitian ini merupakan penelitian observasional dengan menggunakan rancangan penelitian Cross Sectional. Penelitian hanya melaksanakan pengamatan saja tanpa melakukan intervensi, pengukuran variabel pada satu saat hanya diobservasi satu kali saja dan pengukuran variabel subjek dilakukan saat pemeriksaan. Subjek penelitian adalah seluruh anak balita yang berjumlah 472 balita berumur 12 sampai 60 bulan yang datang menimbang ke posyandu pada bulan November 2008.

Penelitian dilakukan di wilayah kerja Puskesmas Galur II, Kecamatan Galur, Kabupaten Kulon Progo, Provinsi DIY dengan waktu penelitian selama 3 bulan yaitu mulai September -Desember 2008. Variabel penelitian meliputi variabel independen yaitu frekuensi konsumsi growol, sedangkan variabel dependen adalah kejadian diare.

Jenis data meliputi data primer dan data sekunder. Data primer meliputi: frekuensi konsumsi growol, kejadian diare subjek penelitian dan karakteristik subjek penelitian. Data sekunder meliputi: gambaran umum wilayah penelitian dan sasaran program kegiatan puskesmas.

Data kejadian diare dan karakteristik subjek penelitian dikumpulkan melalui wawancara menggunakan kuesioner. Angka kejadian diare dikumpulkan dalam mulai bulan November 2007-Oktober 2008. Data frekuensi konsumsi growol subjek penelitian satu bulan terakhir dikumpulkan 
dengan menggunakan Food Frequency Questionnaire (FFQ). Data tentang frekuensi konsumsi growol diperoleh dari hasil wawancara langsung dengan ibu responden dengan menggunakan panduan kuesioner dan tabel food frequency. Pengambilan data dilakukan oleh kader posyandu, tiap posyandu seorang kader bertugas mengambil data. Jumlah keseluruhan pengambil data ada 30 orang (enumerator). Sebelum enumerator mengambil data oleh peneliti dijelaskan terlebih dahulu tentang isi dari kuesioner

Data tentang gambaran umum wilayah penelitian diperoleh dari arsip administrasi di kantor desa dan Kecamatan Galur, sedangkan data sasaran program kegiatan puskesmas diperoleh dari profil Puskesmas Galur II Kecamatan Galur, Kabupaten Kulon Progo, Provinsi DIY.

Pengolahan dan analisis data dilakukan dengan menggunakan program software komputer. Analisis data yang dilakukan adalah analisis univariat dan bivariat. Hubungan antara variabel bebas dan variabel terikat dianalisis menggunakan uji Wilcoxon dan Regresi, pengukuran faktor kecenderungan dengan menghitung odds ratio (OR).

\section{HASIL}

\section{Karakteristik subjek}

Awalnya subjek penelitian berjumlah 426 balita , namun akhirnya diambil semua balita yang datang menimbang di posyandu pada bulan November 2008 serta memenuhi kriteria inklusi dan eksklusi sebanyak 472 balita. Kriteria inklusi ialah balita yang datang pada kegiatan Posyandu bulan November 2008, bersedia ikut penelitian dan berumur 1-5 tahun. Sementara kriteria eksklusi ialah yang menderita gizi buruk. Selengkapnya bisa dilihat di Tabel 1.

Tabel 1. Distribusi subjek berdasarkan jenis kelamin

\begin{tabular}{llllllc}
\hline \multirow{2}{*}{ Desa } & \multicolumn{2}{c}{ Laki-laki } & \multicolumn{2}{c}{ Perempuan } & Jumlah & $\begin{array}{c}\text { Persentase } \\
\text { (\%) }\end{array}$ \\
\cline { 2 - 5 } & \multicolumn{1}{c}{$\mathbf{n}$} & \multicolumn{1}{c}{$\boldsymbol{n} \mathbf{n}$} & $\mathbf{\%}$ & & \\
\hline Nomporejo & 58 & 23,7 & 44 & 19,3 & 102 & 21,6 \\
Banaran & 121 & 49,6 & 124 & 54,4 & 245 & 51,9 \\
Kranggan & 65 & 26,7 & 60 & 26,3 & 125 & 26,5 \\
Jumlah & 244 & 100 & 228 & 100 & 472 & 100 \\
\hline
\end{tabular}

Distribusi subjek berdasarkan jenis kelamin antara lakilaki dan perempuan hampir sama yaitu laki-laki $52 \%$ dan perempuan $48 \%$. Pengelompokan berdasarkan jenis kelamin dimaksudkan untuk menunjukkan homogenitas subjek.
Tabel 2. Distribusi subjek berdasarkan kelompok umur

\begin{tabular}{ccc}
\hline $\begin{array}{c}\text { Kelompok umur } \\
\text { (bulan) }\end{array}$ & Jumlah & $\begin{array}{c}\text { Persentase } \\
\text { (\%) }\end{array}$ \\
\hline $12-24$ & 126 & 26,66 \\
$25-36$ & 110 & 23,33 \\
$37-48$ & 122 & 25,86 \\
$49-60$ & 114 & 24,15 \\
Jumlah & 472 & 100 \\
\hline
\end{tabular}

Distribusi subjek berdasarkan kelompok umur dalam bulan hampir merata, tetapi persentase tertinggi pada kelompok umur 12 - 24 bulan sebanyak $26,66 \%$. Pengelompokan berdasarkan umur ini sesuai dengan kriteria usia balita yaitu baduta, batita dan balita (Tabel 2).

\section{Frekuensi konsumsi growol}

Berdasarkan wawancara dengan masyarakat di wilayah kerja Puskesmas Galur II ada 3 jenis growol yaitu growol biasa, growol manis dan growol goreng. Dari ketiga jenis growol tersebut yang paling dapat diterima balita adalah growol manis, yang dapat dikonsumsi baik sebagai pengganti nasi maupun sebagai camilan. Masyarakat memperoleh growol dari membeli di pasar tradisional setiap 5 hari sekali (sepasaran Jawa) atau di pedagang sayur keliling yang berkeliling setiap hari.

Subjek yang tidak mengkonsumsi growol sebanyak 312 balita (66\%) sedangkan yang mengkonsumsi growol 160 balita (34\%). Frekuensi konsumsi growol mulai dari seminggu sekali sampai yang paling sering adalah seminggu hingga 15 kali, rata-rata dalam satu minggu subjek mengkonsumsi growol sebanyak 3,8 kali, dan modus yang paling sering adalah 2 kali seminggu sebanyak 36 subjek (Tabel 3).

Tabel 3. Distribusi subjek berdasarkan frekuensi konsumsi growol dalam 1 minggu

\begin{tabular}{ccccccc}
\hline \multirow{2}{*}{$\begin{array}{c}\text { Kelompok } \\
\text { umur }\end{array}$} & \multicolumn{2}{c}{ Pernah diare } & \multicolumn{2}{c}{$\begin{array}{c}\text { Tidak pernah } \\
\text { diare }\end{array}$} & Jumlah & $\%$ \\
\cline { 2 - 5 } & $\mathbf{n}$ & $\%$ & $\mathbf{n}$ & $\%$ & & \\
\hline $12-24$ & 36 & 28,5 & 90 & 71,5 & 126 & 100 \\
$25-36$ & 23 & 20,9 & 87 & 79,1 & 110 & 100 \\
$37-28$ & 21 & 17,2 & 101 & 82,8 & 122 & 100 \\
$49-60$ & 26 & 22,8 & 88 & 77,2 & 114 & 100 \\
Jumlah & 106 & 22,46 & 366 & 77,54 & 472 & 100 \\
\hline
\end{tabular}

Distribusi subjek yang pernah diare sebanyak 106 subjek $(22,46 \%)$ dan yang tidak pernah diare sebanyak 366 subjek $(77,54 \%)$. Kelompok umur $12-24$ bulan adalah kelompok umur yang paling banyak pernah diare yaitu 36 subjek $(7,62 \%)$. 


\section{Angka Kejadian Diare}

Ada hubungan yang signifikan antara frekuensi konsumsi growol dengan kejadian diare ini dibuktikan dengan menggunakan uji regresi diperoleh persamaan linier: $Y=0,474-0,074 X$ di mana $Y$ adalah kejadian diare dan $X$ adalah frekuensi konsumsi growol. Dari persamaan linier tersebut diketahui bahwa jika $X=0$ maka kemungkinan menderita diare sebesar 0,474 atau $47,4 \%$, dan jika $Y=0$ maka nilai $X$ adalah 6,4 artinya growol dapat mencegah kejadian diare jika dikonsumsi minimal 6,4 kali dalam satu minggu.

Angka kejadian diare adalah jumlah kali episode diare yang terjadi selama satu tahun dari bulan November
2007 - Oktober 2008 di wilayah kerja Puskesmas Galur II, Kecamatan Galur, Kulon Progo.

Distribusi subjek yang pernah diare 106 subjek $(22,46 \%)$ dan yang tidak pernah diare 316 subjek $(77,54 \%)$. Kelompok umur 12 - 24 bulan adalah kelompok umur yang paling banyak pernah diare yaitu 36 subjek $(7,62 \%)$.

\section{Hubungan antara konsumsi growol dengan angka kejadian diare}

Hubungan antara konsumsi growol dengan angka kejadian diare ini membandingkan antara subjek yang mengkonsumsi growol dengan yang tidak dengan kejadian diarenya.

Tabel 4. Distribusi subjek antara pernah diare dan tidak pernah selama tahun 2007

\begin{tabular}{ccccccc}
\hline \multirow{2}{*}{ Kelompok umur } & \multicolumn{2}{c}{ Pernah diare } & \multicolumn{2}{c}{ Tidak pernah diare } & Jumlah & $\mathbf{( \% )}$ \\
\cline { 2 - 7 } & $\mathbf{n}$ & $\mathbf{\%}$ & $\mathbf{n}$ & $\mathbf{\%}$ & & \\
\hline $12-24$ & 36 & 28,5 & 90 & 71,5 & 126 & 100 \\
$25-36$ & 23 & 20,9 & 87 & 79,1 & 110 & 100 \\
$37-28$ & 21 & 17,2 & 101 & 82,8 & 122 & 100 \\
$49-60$ & 26 & 22,8 & 88 & 77,2 & 114 & 100 \\
Jumlah & 106 & 22,46 & 366 & 77,54 & 472 & 100 \\
\hline
\end{tabular}

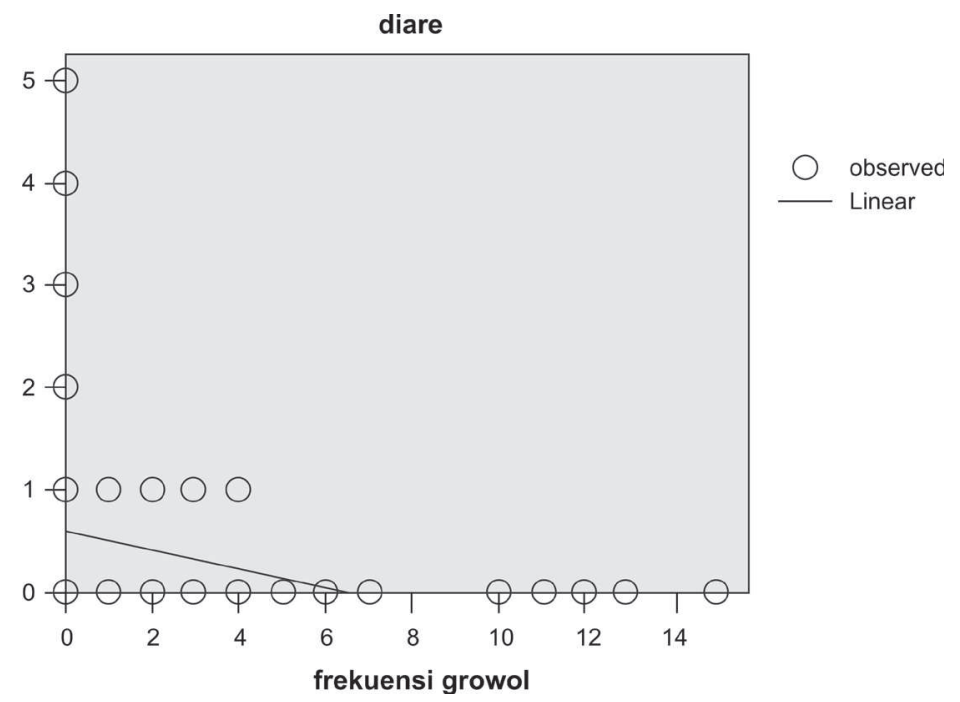

Gambar 1. Hubungan antara frekuensi growol dengan angka kejadian diare

Tabel 5. Kejadian diare antara yang dikonsumsi growol dan yang tidak dikonsumsi

\begin{tabular}{ccccccccc}
\hline \multirow{2}{*}{ Konsumsi } & \multicolumn{2}{c}{ Diare } & \multicolumn{2}{c}{ Tidak diare } & \multirow{2}{*}{ Jumlah } & (\%) & p \\
\cline { 2 - 5 } & $\mathbf{n}$ & $\mathbf{\%}$ & $\mathbf{n}$ & $\mathbf{\%}$ & & 160 & 100 & 0,00 \\
Ya & 12 & 7,5 & 148 & 92,5 & & 100 & \\
\hline
\end{tabular}


Berdasarkan Tabel 5 dapat dilihat bahwa kejadian diare dari 160 subjek yang mengkonsumsi growol adalah 12 subjek $(7,5 \%)$, sedangkan dari 312 subjek yang tidak mengkonsumsi growol pernah diare sebanyak 94 subjek $(30,12 \%)$. Kedua kelompok subjek baik yang mengkonsumsi growol maupun yang tidak mengkonsumsi growol sama-sama ada yang pernah diare, hanya saja pada kelompok yang tidak mengkonsumsi growol persentasenya lebih tinggi yaitu 4 kali lipat.

\section{Hubungan antara frekuensi konsumsi growol dengan angka kejadian diare}

Hubungan antara frekuensi konsumsi growol dengan angka kejadian diare dalam penelitian ini menghubungkan jumlah kali konsumsi growol oleh subjek dalam jangka waktu 1 minggu dengan kejadian diare yang dialami subjek selama 1 tahun terakhir yaitu dari bulan Nopember 2007 - Oktober 2008. Berdasarkan Gambar 1 dapat dilihat bahwa semakin besar frekuensi konsumsi growol semakin kecil angka kejadian diarenya.

\section{BAHASAN}

Hubungan antara yang mengkonsumsi dan yang tidak mengkonsumsi growol dengan angka kejadian diare

Ada perbedaan pada angka kejadian diare antara yang mengkonsumsi dan yang tidak mengkonsumsi growol, ini ditunjukkan dengan hasil analisis statistik dengan metode Wilcoxon. Berdasarkan hasil analisis metode Wilcoxon diperoleh $p=0,00(p<0.05)$ sehingga dapat disimpulkan bahwa ada perbedaan kejadian diare yang signifikan antara subjek yang mengkonsumsi growol dengan yang tidak mengkonsumsi growol (Tabel 4).

Perbedaan kejadian diare pada subjek yang mengkonsumsi growol dengan yang tidak mengkonsumsi growol ini disebabkan karena growol mengandung Lactobacillus casei subsp. Rhamnosus TGR2 yang memiliki potensi aktivitas antimikrobia penyebab diare (7). Etiologi diare yang paling sering terjadi adalah virus (rotavirus) sebesar $32,6 \%$ dan bakteri sebesar 5,8\% (Aeromonas hydrophilla, Salmonella grup B, Campylobacter jejuni).

Hal ini sesuai dengan penelitian mengenai potensi probiotik yang dilakukan oleh Saavendra (5) dan Bezkorovainy (6) yang menyebutkan bahwa Lactobacillus rhamnosus $G G$ efektif dalam mencegah diare, mengatasi diare akut baik pada anak maupun orang dewasa serta memperpendek durasi diare.

Angka kejadian diare ini dilihat berdasarkan kelompok umur sesuai dengan penelitian yang dilakukan oleh Bresee et al. puncak kejadian diare pada usia 6 bulan hingga 24 bulan. Hal itu disebabkan karena pada umur 12-24 bulan balita sedang dalam masa pengenalan makanan kasar, dari yang sebelumnya hanya ASI (0-6 bulan) (12).

\section{Hubungan antara frekuensi konsumsi growol dengan kejadian diare}

Hubungan antara frekuensi growol dengan angka kejadian diare menghubungkan jumlah kali konsumsi growol oleh subjek dalam jangka waktu 1 minggu. Penelitian yang dilakukan oleh Gibson, yaitu jika bahan yang mengandung probiotik tidak lagi dikonsumsi, maka bakteri yang menguntungkan itu dengan cepat akan mengalami wash - out atau habis, sehingga bahan yang mengandung probiotik itu harus dikonsumsi secara terus-menerus. Oleh karena itu, untuk mencegah kejadian diare maka growol harus dikonsumsi secara terus menerus minimal 6,4 kali per minggu (13).

Semakin besar frekuensi konsumsi growol semakin kecil angka kejadian diarenya atau berbanding terbalik antara frekuensi konsumsi growol dengan angka kejadian diare. Hal ini sesuai penelitian yang menghasilkan kesimpulan bahwa pemberian probiotik pada bayi usia 5 sampai 24 bulan akan mengalami penurunan angka kejadian diare akibat infeksi oleh rotavirus sebesar $10 \%$ - 39\% (14). Begitu juga dengan hasil penelitian di RS. Dr. Soedarso Pontianak yang menyatakan bahwa anak yang lebih muda menderita diare cenderung untuk dirawat lebih lama (22).

Probiotik merupakan mikroorganisme hidup yang bila diberikan dalam jumlah sesuai, akan memberikan manfaat bagi tubuh dan membantu mempertahankan saluran pencernaan selalu dalam kondisi sehat. Sedangkan prebiotik adalah komponen makanan yang tidak dapat dicerna oleh sistem pencernaan (serat kasar), namun mampu merangsang pertumbuhan dan aktivitas mikroflora di saluran pencernaan secara efektif. Prebiotik merupakan makanan atau substrat bagi probiotik (15).

Growol adalah makanan khas daerah Kulon Progo, dibuat dari singkong yang direndam dalam air selama 4 hari. Selama perendaman ini terjadi fermentasi alami yang akan menghasilkan Bakteri Asam Laktat (BAL) yang berpotensi sebagai probiotik alami, jumlah BAL pada growol tiap gramnya sebesar 1,64 x 108 (10). Jumlah BAL tersebut sudah mampu untuk mempertahankan keseimbangan mikroflora usus yang sehat, seperti dalam penelitian Shah menjelaskan bahwa untuk bisa memberikan efek kesehatan, bakteri probiotik haruslah hidup dan tersedia dalam konsentrasi yang tinggi minimal $106 \mathrm{cfu} / \mathrm{g}$ produk (16).

Kadar serat total singkong sebesar 5,4 gram/100 gram sedangkan untuk serat kasarnya (tidak larut air) sebesar $1,8 \mathrm{gram} / 100$ gram. Kadar serat kasar yang tinggi ini berfungsi sebagai prebiotik yang akan menjadi makanan bagi probiotik untuk kelangsungan hidupnya di saluran pencernaan (17).

Probiotik dan prebiotik merupakan perpaduan yang sinergis yang dapat mempertahankan fungsi saluran pencernaan selalu sehat. Kedua komponen ini bekerja 
di saluran pencernaan dengan cara menstimulasi sel-sel usus yang sehat, menghambat pertumbuhan dan aktivitas bakteri patogen serta menstimulasi respon sistem daya tahan tubuh (15). Growol selain mengandung probiotik juga mengandung prebiotik sehingga dapat dipakai sebagai pangan fungsional untuk upaya pencegahan diare.

Beberapa spesies bakteri probiotik indigenous (lokal) yang dilaporkan bermanfaat untuk treatment diare antara lain Lactobacillus sp Dad 13 (dari dadih), Lactobacillus plantarum Mut7 dan Lactobacillus sake Mut13 (dari gatot). Penelitian secara in vitro yang dilakukan di Yogyakarta memperlihatkan bahwa bakteri dan metabolit Lactobacillus sp Dad 13 (dari dadih), Lactobacillus plantarum Mut7 dan Lactobacillus sake Mut13 (dari gatot), mampu menghambat pertumbuhan bakteri Salmonella cholerasius penyebab diare. Begitu juga dengan hasil penelitian secara in vitro di Yogyakarta menyatakan bahwa bakteri dan metabolit Lactobacillus sp Dad 13 (dari dadih), Lactobacillus plantarum Mut7 dan Lactobacillus sake Mut13 (dari gatot) mampu menghambat pertumbuhan bakteri Shigella $s p$ penyebab diare (disentri) (19).

Hasil penelitian yang dilakukan di Yogyakarta secara in vitro menunjukkan bahwa bakteri probiotik dari Lactobacillus plantarum Mut7 (dari gatot) mampu menghambat beberapa bakteri pathogen yaitu Salmonella typhi, Staphylococcus aereus, dan E. Coli (18).

Keuntungan dari sumber probiotik indigenous (lokal) ini adalah berupa makanan (bukan dalam bentuk kapsul, tablet atau bubuk) yang berasal dari bahan alami, merupakan bahan makanan yang dikonsumsi dari bagian diet sehari-hari dan memiliki fungsi khusus bila dikonsumsi. Keuntungan dari growol sebagai sumber probiotik indigenous (lokal) adalah karena murah, sebagai pengganti nasi sehingga dapat dikonsumsi setiap hari (terus menerus) dan sudah terbukti aman dikonsumsi (tidak beracun).

\section{KESIMPULAN DAN SARAN}

Frekuensi konsumsi growol pada anak balita di wilayah kerja Puskesmas Galur II sebesar 34\%; dan ada hubungan yang signifikan antara frekuensi konsumsi growol dengan angka kejadian diare. Semakin tinggi frekuensi konsumsi growol semakin kecil kemungkinan terkena diare. Untuk mencegah kejadian diare frekuensi konsumsi growol minimal 6,4 kali/minggu. Subjek yang tidak mengkonsumsi growol mempunyai kemungkinan menderita diare sebesar 47,4\% dibandingkan subjek yang mengkonsumsi growol.

Beberapa saran yang bisa diberikan yaitu perlu adanya sosialisasi untuk mengkonsumsi growol kepada balita pada umumnya dan khususnya balita Galur untuk mencegah kejadian diare. Perlu dilakukan penelitian selanjutnya agar mempertimbangkan kelemahan penelitian ini yaitu: bias informasi dari subjek berkaitan dengan pengingatan kembali tentang kejadian yang telah terjadi satu bulan terakhir dan penelitian tidak mempertimbangkan penyebab diare, sehingga kemungkinan bias tetap ada.

\section{RUJUKAN}

1. Glass RI, Bresee JS, Turcies R, Fischer TK, Parashar UD, Steele AD. Rotavirus vaccines: targeting the developing world. J.Infect.Dis 2005; 192: S160-S6.

2. Winarno. Flora Usus: Menjaga Kesehatandan Kebugaran [serial online] 2007 [cited 2008 Jun 16]. Avalaible from: http:// www.republika.co.id/teknologi pangan dan gizi id=204933.

3. Antoinne MJ. Probiotic for Optimum Health [serial online] 2007 [cited 2008 Jun 16]. Avalaible from: http:// www.solaraid. Org.

4. Roberfroid MB. Prebiotics and probiotics: are they functional food? Am J Clin Nutr 200071 (61):1682S$7 \mathrm{~S}$.

5. Saavendra JM. Clinical applications of probiotic agents. Am J Clin Nutr 2001; 73 (6):1147S-51S.

6. Bezkorovainy A. Probiotcs:determinant of survival and growth in the gut. Am J Clin Nutr 2001; 73 (2): 399S405S.

7. Rahayu ES, TF Djafar, D Wibowo dan S Sudarmadji. Lactic Acid Bacteria from Indigenous Fermented Foods and Their Antimicrobial Activity.Indonesia Food and Nutrition Progress 1996; 3(2):21-8.

8. Sumaryati BT. Potensi Kombinasi Bakteri Asam Laktat dan Inulin untuk Mencegah Diare Akibat Infeksi E.Colli Patogenik. Yogyakarta: Tesis S2 Program Pasca Sarjana UGM; 2006

9. Rahayu ES. Bacteriocinsof Lactic Acid Bacteria: characterization, production, and food application. The 2nd Indonesian Biotech Conference 2001; 309-18.

10. Suharni TT. Laporan Penelitian: Pembentukan asam-asam organic oleh bakteri yang berperan pada suatu produk ketela pohon yang difermentasikan. Yogyakarta: Fakultas Biologi UGM; 1984.

11. Rahayu ES, TF Djafar, D Wibowo, S Sudarmadji. Laporan Penelitian:Isolasi Bakteri Asam Laktat dan Karakterisasi Agensia yang berpotensi sebagai Biosafety makanan Indonesia. Yogyakarta: PAU Pangan dan Gizi UGM; 1995.

12. Bresee,J. Fang ZY, Wang B, Nelson EA, Tam J, Soenarto Y, Wilopo SA.

13. Gibson,G.R., Probiotics and Prebiotics: gut microflora management for improved health. Medical Progress 2000; 27 (No.2):34 - 6.

14. Saavendra,J.M .Clinical applications of probiotic agents. Am J Clin Nutr 2001; 73 (6):1147S-51S.

15. Roberfroid,MB. Prebiotics and probiotics: are they functional food? Am J Clin Nutr 2000; 71(61):1682S$7 \mathrm{~S}$. 
16. Shah NP. Functional Food from Probiotic and Prebiotics Food Technology 2001: 55 (11):46-53.

17. Almatsier S. Penuntun Diet edisi baru. Jakarta: PT Gramedia Pustaka Utama; 2007.

18. Permatasari O. Kemampuan Penghambatan Bakteri Probiotik dari Dadih dan Gatot terhadap Bakteri Shigella sp Penyebab Diare secara in vitro. Yogyakarta: Prodi Gizi Kesehatan Fakultas Kedokteran UGM; 2007.

19. Palupi IR. Kemampuan Penghambatan Bakteri Probiotik dari Dadih dan Gatot terhadap Bakteri Salmonella Choleraesius Penyebab Diare secara in vitro. Yogyakarta: Prodi Gizi Kesehatan Fakultas Kedokteran UGM; 2007.
20. Surono IS. Probiotic Properties of Indigenous Dadih Lactic Acid Bacteria. The 2nd Indonesian Biotech Conference 2001; p.288-95.

21. Palupi A, Hadi H, Soenarto SS. Status Gizi dan Hubungannya dengan Kejadian Diare Pada Anak Diare Akut di Ruang Rawat Inap RSUP Dr. Sardjito Yogyakarta. Jurnal Gizi Klinik Indonesia 2009; 6(1) :1-7.

22. Gambir J, Julia M, Juffrie M. Pengaruh Suplementasi Zink ( $\mathrm{Zn}$ ) terhadap Diare pada Penderita Umur 6 - 36 Bulan yang Dirawat RS Dr. Sardjito Yogyakarta. Jurnal Gizi Klinik Indonesia 2005; 1(3) : 113-8. 